\title{
Magma flow inferred from magnetic fabrics in Wanning gabbro pluton and diabase dykes, Hainan
}

\author{
PAN XiaoQing, SHEN ZhongYue*, DONG ChuanWan, CHEN HanLin, CHENG XiaoGan, \\ YANG ShuFeng \& ZHANG ZhiLiang
}

Department of Earth Sciences, Zhejiang University, Hangzhou 310027, China

Received January 2, 2012; accepted February 9, 2012; published online March 23, 2012

\begin{abstract}
Measurements of anisotropy of magnetic susceptibility (AMS) were performed on a gabbro pluton and 7 diabase dykes in the Wanning area, southeast Hainan Island. Rock magnetism showed that pseudo-single domain (PSD) to multidomain (MD) Ti-poor magnetite carries the magnetic fabric in the gabbro pluton whereas MD Ti-poor magnetite carries the magnetic fabric in the diabase dykes. The corrected anisotropy degree $\left(P_{j}\right)$ in most specimens was found to be less than 1.2 which is indicative of a possible flow-related magnetic fabric. The AMS eigenvectors within each site are generally well grouped. The maximum susceptibility axes $\left(K_{1}\right)$ of the gabbro pluton are inclined towards the north at low angles $\left(<30^{\circ}\right) . K_{1}$ axes of the diabase dykes are inclined towards the NNW and SSE with dip angles of $\leqslant 30^{\circ}$. From this study, it appears that the emplacement mode of the gabbro pluton was characterized by intrusion from the north to the south at a low angle whereas the diabase dykes were emplaced from the NNW to the SSE at low to moderate angles. This was verified by comparison of the rock fabric to the magnetic fabric. All of this evidence leads to the conclusion that the Wanning gabbro pluton and diabase dykes were the products of pulsative intrusion from the same magma chamber in the area far to the north of Wanning, which suggests that basic rocks may exist beneath the Indosinian granite in the area to the north of Wanning.
\end{abstract}

Hainan AMS, emplacement mode, basic pluton, basic dyke

Citation: Pan X Q, Shen Z Y, Dong C W, et al. Magma flow inferred from magnetic fabrics in Wanning gabbro pluton and diabase dykes, Hainan. Chin Sci Bull, 2012, 57: 1982-1989, doi: 10.1007/s11434-012-5054-x

The anisotropy of magnetic susceptibility (AMS) is defined as the variation in direction of the principal magnetic susceptibility axes within a rock sample. AMS is approximated by a second rank tensor, which can be described by an ellipsoid with three principal eigenvectors $K_{1}, K_{2}$, and $K_{3}$ $\left(K_{1}>K_{2}>K_{3}\right)$. The origin of AMS is mainly related to three factors: (1) orientation of grains, i.e. shape anisotropy [1], (2) distribution of grains, i.e. distribution anisotropy [2], and (3) alignment of magnetic domains, i.e. domain anisotropy [3]. AMS in intrusive rocks is always related to the process of magma emplacement and crystallization. Accordingly, emplacement mechanisms of plutons, dykes and even their magmatic source or vent position can be determined using AMS [4].

\footnotetext{
*Corresponding author (email: gs_zshen@zju.edu.cn)
}

Half a century ago, Khan [5] verified that AMS has a relationship with the preferred orientation of the long axes of magnetite grains in some igneous and metamorphic rocks [5]. Knight and Walker [6] performed the principal work using AMS in nearly isotropic mafic dykes of the Koolau Complex (Ohau, Hawaii). Since then the measurement of AMS has been increasingly utilized as a rapid and sensitive method of determining magma flow in plutons and dykes [5-13].

A seminal idea was proposed by Rochette et al. $[7,8]$ and Tauxe et al. [9] that magnetic fabric could be divided into three categories, namely normal, intermediate and inverse fabric. Normal magnetic fabric is characterized by the clustering of $K_{1}-K_{2}$ axes on the dyke wall whereas $K_{3}$ axes will be nearly perpendicular to it. Inverse magnetic fabric was defined by the $K_{2}-K_{3}$ plane being parallel to the dyke wall 
and $K_{1}$ axes being nearly perpendicular to it. Following the work of Rochette [7,8], only normal magnetic fabric is considered reliable for inferring magma flow direction [6-18].

The studied gabbro pluton and 7 diabase dykes are located in the Wanning area, southeast of Hainan Island. The geochronology and geochemistry of the Wanning gabbro pluton and diabase dykes has been studied by Tang [19] which suggests that they were emplaced in an intracontinental, extensional tectonic setting. Nevertheless, the emplacement mechanism of the Wanning gabbro pluton and diabase dykes remains unknown. This paper is therefore a preliminary study concerning this question by applying the measurements of AMS and rock fabric.

\section{Geological setting and sampling}

Mesozoic volcanic and intrusive rocks are widely distributed in central and southern Hainan Island. In the area south of the Wangwu-Wenjiao fault zone, Hercynian-Indosinian and Yanshanian granites commonly crop out. Among the granites is the Indosinian, hornblende gabbro pluton which has been intruded by a series of $\mathrm{N}-\mathrm{S}$-trending diabase dykes. This outcrop in the Wanning area provides a good opportunity to study Mesozoic magmatic activities and regional tectonic features of Hainan Island.

The Wanning hornblende gabbro pluton which crops out north of the Wanning reservoir in Wanning City (SE of Hainan Island) covers an area of about $120 \mathrm{~km}^{2}$. The main minerals in the pluton include plagioclase $(\sim 65 \%)$, hornblende $(\sim 25 \%)$ and pyroxene $(\sim 4 \%)$. Accessory minerals account for about $2 \%$; consisting of magnetite, zircon and apatite. Similar hornblende gabbros also crop out in both
Biandu village $\left(18^{\circ} 43.251^{\prime} \mathrm{N}, 110^{\circ} 11.516^{\prime} \mathrm{E}\right)$ to the $\mathrm{SW}$ of Wanning reservoir and Lingweipo village $\left(18^{\circ} 41.843^{\prime} \mathrm{N}\right.$, $110^{\circ} 18.619^{\prime} \mathrm{E}$ ) to the south of Wanning (Figure 1). In the riverbed $\mathrm{NE}$ of the reservoir dam, at least 8 diabase dykes have intruded the Wanning hornblende gabbro pluton (Figure 2). The grayish black, N-S-trending dykes are well exposed with vertical to subvertical dips and thicknesses in the range of $20-80 \mathrm{~cm}$. The boundaries between different dykes and the host rocks are distinct. Lithologically, all of the studied dykes are hornblende diabase with a porphyritic texture: about $6 \%$ phenocrysts of plagioclase and hornblende. The remaining matrix has a similar mineral composition to the phenocrysts, with anhedral to subhedral grains forming an intergranular texture. Accessory minerals consist of magnetite, zircon and apatite. Zircon $\mathrm{U}-\mathrm{Pb}$ isotopic ages of the Wanning gabbro pluton and diabase dykes have been found to be $240 \pm 2 \mathrm{Ma}$ and $235.8 \pm 2.8$ Ma respectively [19].

We drilled cores using a portable gasoline drill and samples were oriented using a magnetic compass. The 61 oriented cores were drilled from the gabbro pluton. 53 oriented cores were drilled across 7 dyke profiles at 5-10 cm intervals (Figure 2). Seven oriented cores were drilled from the Biandu gabbro. Each core was cut into 1 to 2 standard cylindrical specimens of $2.5 \mathrm{~cm}$ in diameter and $2.2 \mathrm{~cm}$ in length. We collected a total of 155 specimens.

\section{Rock magnetism}

\subsection{Saturated isothermal remanent magnetization (SIRM) acquisition curves and remanent coercivity spectra}

Saturated isothermal remanent magnetization (SIRM)

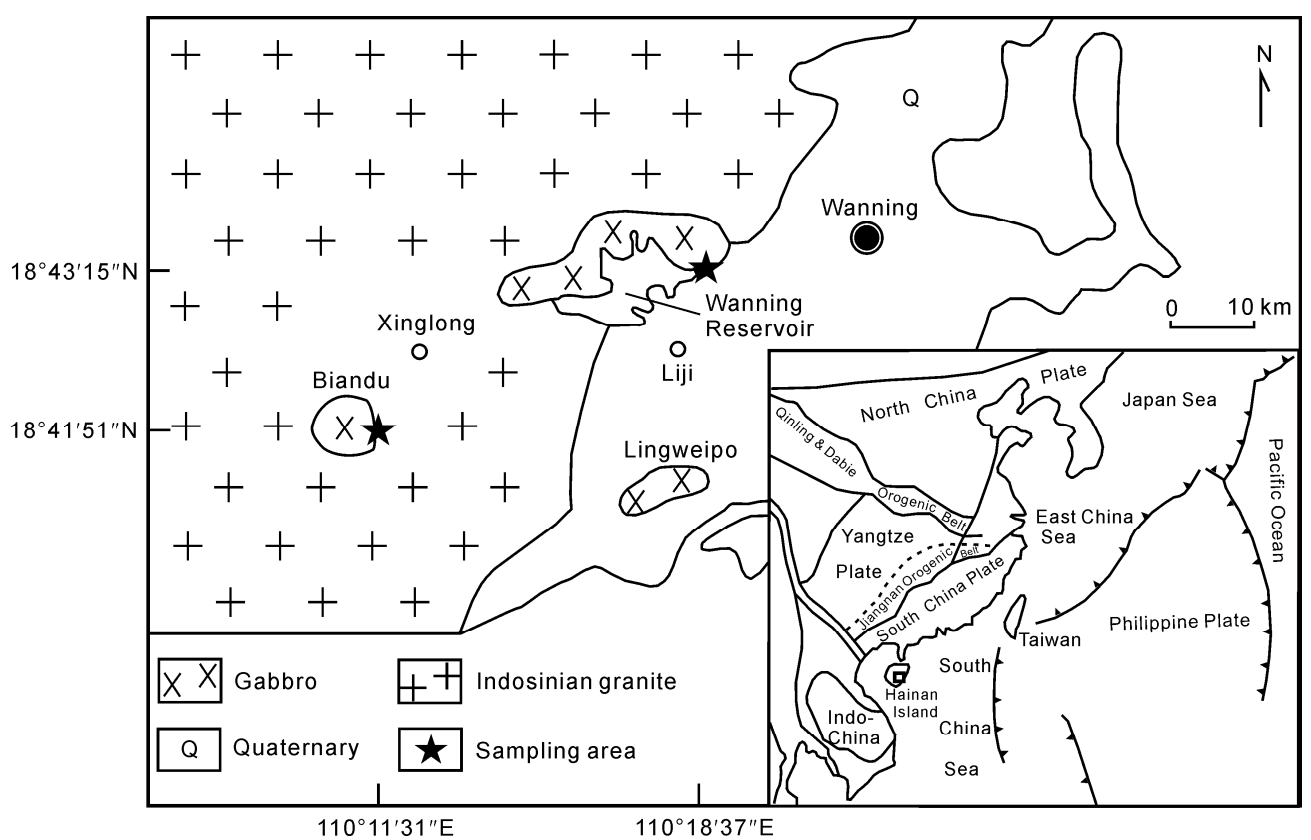

Figure 1 Geological sketch map of Hainan Island and the sampling area. 


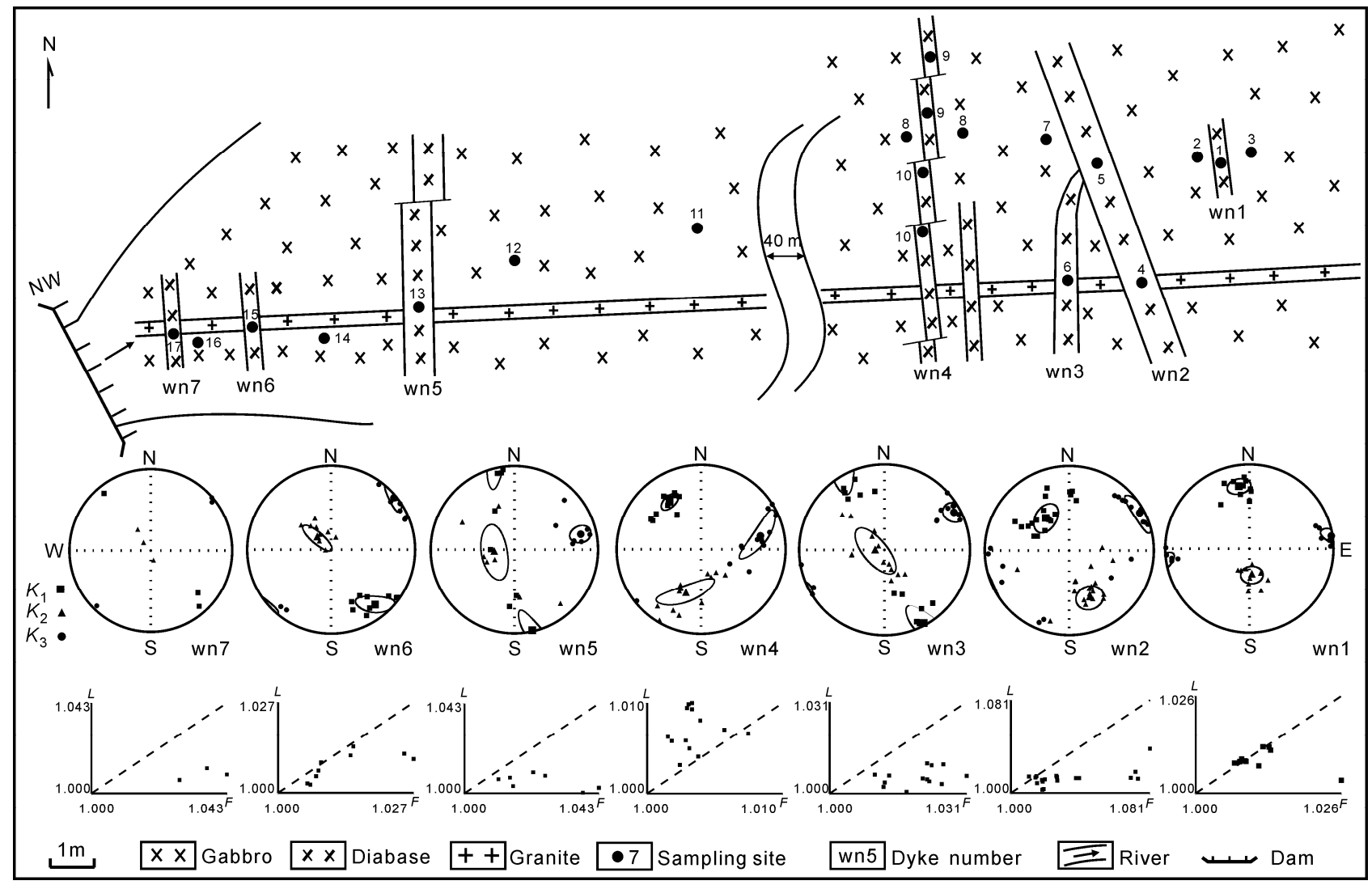

Figure 2 Sampling sites, AMS projections, and Flinn plots of 7 diabase dykes at Wanning (in geographic coordinates).

acquisition curves and remanent coercivity spectra were measured in the Paleomagnetic Laboratory of Zhejiang University. Representative samples selected from the Wanning gabbro and diabases were subjected to isothermal remanent magnetization (IRM) in progressively increasing magnetizing fields using an IM-10-30 pulse magnetometer (ASC Scientific, United States of America). Remanence measurements were done using a JR-6A rotating on magnetometer (AGICO, Czech Republic). As shown in Figure 3, both SIRM acquisition curves are steep in the initial stage of the low applied field, indicating low-coercivity ferromagnetic minerals. The SIRM acquisition curve of the diabase sample (Figure 3(a)) shows IRM reached $80 \%$ of saturation under a magnetic field of $150 \mathrm{mT}$, achieving near-complete saturation at $1000 \mathrm{mT}$. This suggests a low-coercivity ferromagnetic mineral as the main magnetic carrier, with possibly trace high-coercivity magnetic minerals. The SIRM acquisition curve of the gabbro sample (Figure 3(b)) shows IRM was nearly saturated under a $165 \mathrm{mT}$ field, indicative of a low-coercivity ferromagnetic mineral being the main magnetic carrier. The values of remanent coercivity of representative samples (Figure 3) were smaller than $46 \mathrm{mT}$, again suggesting the predominance of low-coercivity ferromagnetic minerals.
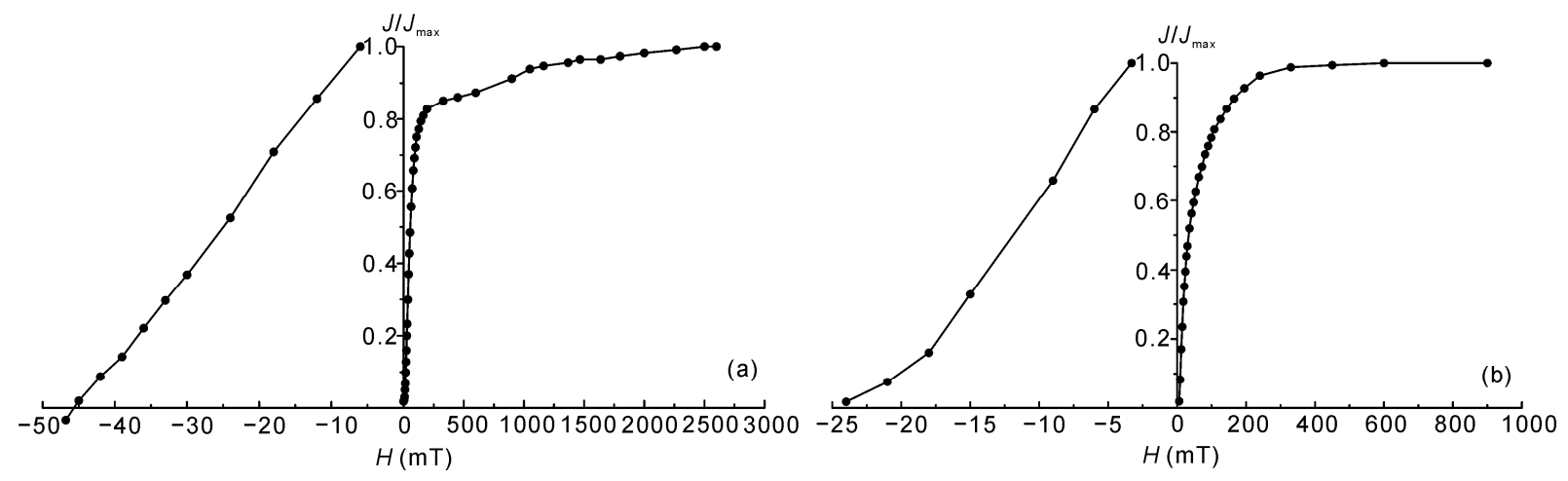

Figure 3 SIRM acquisition curves and Remanent coercivity spectra for (a) Wanning diabase; (b) Wanning gabbro. 


\subsection{Triaxial IRM thermal demagnetization curves}

IRMs were imparted to both gabbro and diabase samples in fields of 100, 400 and $2600 \mathrm{mT}$ at three orthogonal angles. These 3-D IRMs [20] were then thermally demagnetized to yield the unblocking temperature spectra of the coercivities involved in the acquisition of IRM. As shown in Figure 4, the magnetic remanences of gabbro and diabase samples consist mainly of soft magnetic components, in which the intensities of intermediate and hard magnetic components account for $20 \%$ of the total IRM. Two unblocking temperatures at 350 and $550^{\circ} \mathrm{C}$ for the soft magnetic components of the diabase sample (Figure 4(a)) suggest the presence of titanomagnetite or maghemite and Ti-poor magnetite respectively. The unblocking temperatures at 300 and $550^{\circ} \mathrm{C}$ of the gabbro sample (Figure 4(b)) indicate titanomagnetite with different titanium contents and Ti-poor magnetite respectively. In addition, the hard magnetic components of the gabbro sample with an unblocking temperature of $150^{\circ} \mathrm{C}$ (Figure 4(b)) indicates trace amounts of goethite which may
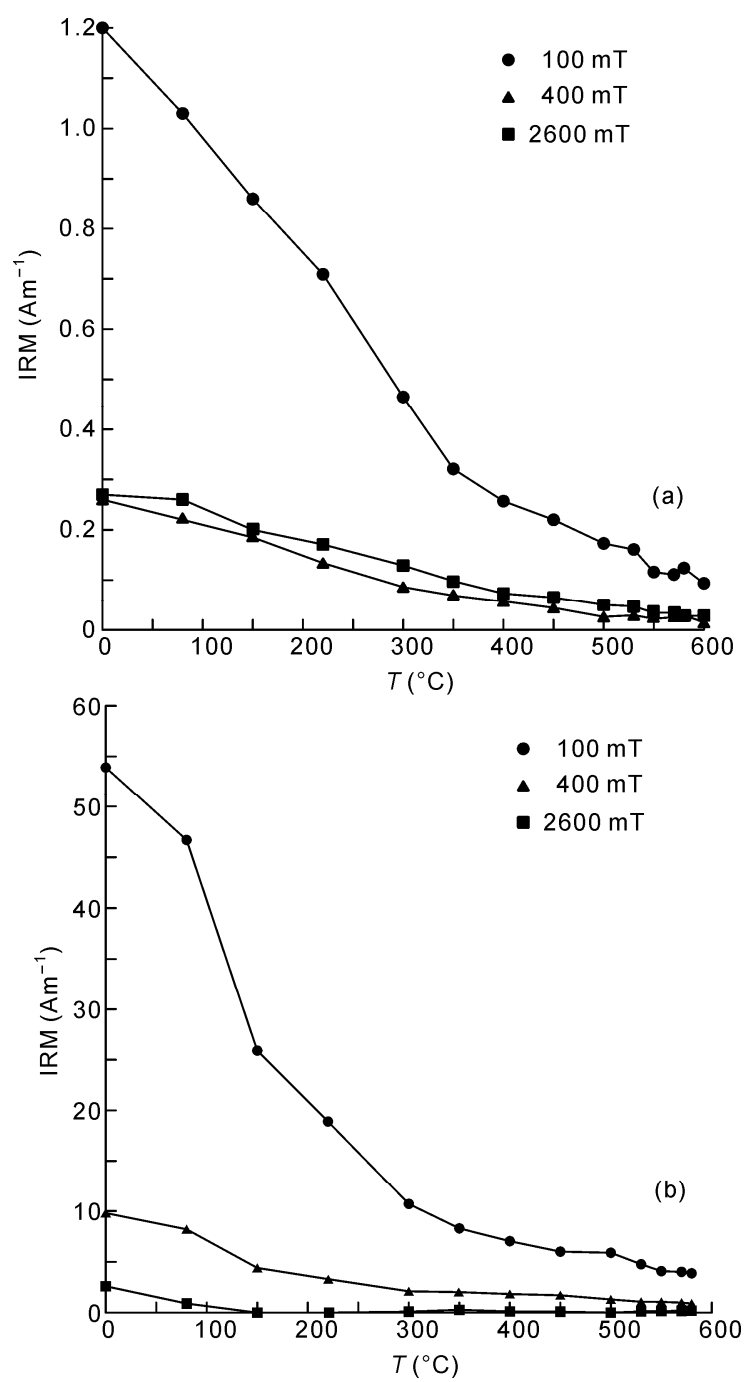

Figure 4 Triaxial IRM thermal demagnetization curves. (a) Wanning diabase; (b) Wanning gabbro. have formed during oxidation of the gabbro at the surface.

\subsection{Hysteresis curves and Day plot}

Hysteresis measurements at room temperature were performed in a vibrating sample magnetometer (MicroMag3900, Princeton Measurements Corporation, United States of America) in fields up to $1000 \mathrm{mT}$. The hysteresis loops of representative diabase samples are linear in shape, revealing the presence of paramagnetic minerals. After removing the effects of paramagnetic minerals, the loop is completely closed under a magnetic field of $200 \mathrm{mT}$, with $M_{\mathrm{rs}} / M_{\mathrm{s}}=0.069 \quad\left(M_{\mathrm{rs}}=\right.$ remanent saturation magnetization; $M_{\mathrm{s}}=$ saturation magnetization $), H_{\mathrm{cr}} / H_{\mathrm{c}}=7.372\left(H_{\mathrm{cr}}=\right.$ coercivity of remanence; $H_{\mathrm{c}}=$ coercivity), suggesting MD magnetite as the main magnetic carrier (Figure 5). The hysteresis loops of representative gabbro samples are narrow-waisted and tend to saturate at $400 \mathrm{mT}$ while not saturating up to 1000 mT. The results show $M_{\mathrm{s}}=20.54 \mu \mathrm{Am}^{2} \mathrm{~kg}^{-1}, H_{\mathrm{c}}=3.843 \mathrm{mT}$, $M_{\mathrm{rs}} / M_{\mathrm{s}}=0.046$, and $H_{\mathrm{cr}} / H_{\mathrm{c}}=3.586$, thus indicating possibly low-coercivity ferromagnetic grains.

The traditional hysteresis parameters $M_{\mathrm{rs}} / M_{\mathrm{s}}$ and $H_{\mathrm{cr}} / H_{\mathrm{c}}$ were plotted in a Day plot $[21,22]$ (Figure 5). From this plot it is clear that all magnetite grains plot in the range from pseudo-single domain (PSD) to multidomain (MD) grain sizes.

\subsection{Thermomagnetic curves}

The magnetic mineralogy of samples can be determined from thermomagnetic curves displaying different Curie temperatures which are mineralogically dependent [23]. Thermomagnetic curves of low field magnetic susceptibility were performed in the Paleomagnetic Laboratory of Nanjing University on representative samples from the Wanning gabbro and diabase dykes (Figure 6). Variable magnetic

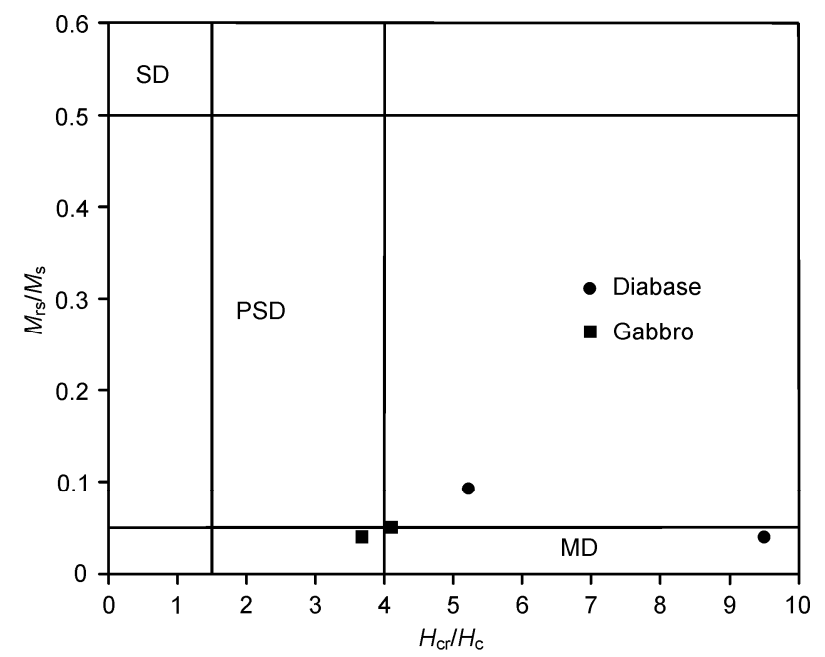

Figure 5 Day plot of magnetic grain-sizes for the Wanning gabbro and diabase dykes. 

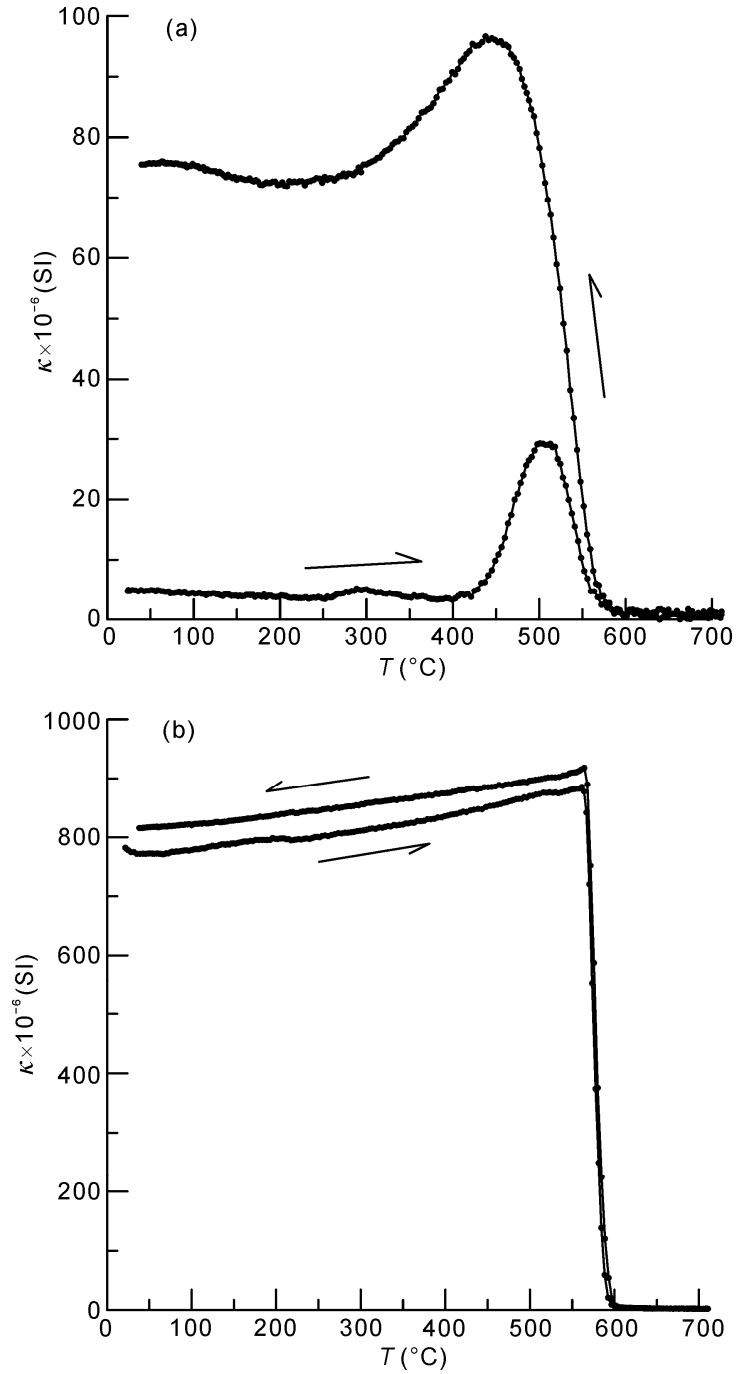

Figure 6 Thermomagnetic curves under argon atmosphere. (a) Wanning diabase; (b) Wanning gabbro.

assemblages in diabase samples were observed. For example, the slight decrease in magnetic susceptibility between room temperature and $250^{\circ} \mathrm{C}$ implies the presence of paramagnetic minerals (Figure 6(a)). The obvious decrease in susceptibility between 300 and $400^{\circ} \mathrm{C}$ and the irreversible curve suggests possible mineralogical transformation of strongly magnetic maghemite to weakly magnetic hematite [24-26]. The sharp increase in susceptibility at $400^{\circ} \mathrm{C}$ and the peak at $500^{\circ} \mathrm{C}$ may be due to paramagnetic and/or clay minerals which have decomposed to magnetite at high temperatures $[27,28]$. The fact that a higher susceptibility is displayed by the cooling curve also reflects the generation of new, strongly magnetic minerals during the heating process (Figure 6(a)). The Curie temperature of about $580^{\circ} \mathrm{C}$ and aforementioned results indicate that MD Ti-poor magnetite is the main magnetic carrier in the diabase samples with some maghemite or titanomagnetite. The reversible thermomagnetic curve with a Curie temperature of $580^{\circ} \mathrm{C}$ (Figure 6(b)) and Day plot (Figure 5) indicate that the main magnetic carrier of gabbro samples is PSD-MD Ti-poor magnetite.

\section{Magnetic fabric}

Anisotropy of magnetic susceptibility (AMS) measurements were performed using a Kappabridge instrument (MFK1-A, AGICO, Czech Republic) in the Paleomagnetic Laboratory of Zhejiang University. AMS is approximated by a second rank tensor, and described by an ellipsoid with three principal eigenvectors $K_{1}, K_{2}$ and $K_{3}$, where $K_{1}>K_{2}>K_{3}$. The parameters [29] adopted here are the mean susceptibility $\left(K_{\mathrm{m}}\right)$, the degree of anisotropy $\left(P_{j}\right)$ and the shape $(T)$ of the fabric, which are expressed by eqs. (1), (2) and (3) respectively.

$$
\begin{gathered}
K_{\mathrm{m}}=\frac{K_{1}+K_{2}+K_{3}}{3}, \\
P_{j}=\exp \sqrt{2 \sum_{i}\left(\ln K_{i} / K_{\mathrm{m}}\right)^{2}} \quad(i=1 \text { to } 3), \\
T=\left(2 \ln K_{2}-\ln K_{1}-\ln K_{3}\right) /\left(\ln K_{1}-\ln K_{3}\right),
\end{gathered}
$$

where $-1 \leqslant T<0$ for a prolate ellipsoid, $T=0$ for a neutral ellipsoid and $0<T \leqslant 1$ for an oblate ellipsoid. AMS results of the Wanning gabbro samples are as follows: mean $T=0.383$, with $86 \%$ samples in the range $0-1$ (oblate ellipsoid); mean $P_{j}=1.129$, with $92 \%$ samples $P_{j} \leqslant 1.2$ (Figure 7(a)). The majority of samples lie within the oblate area in a

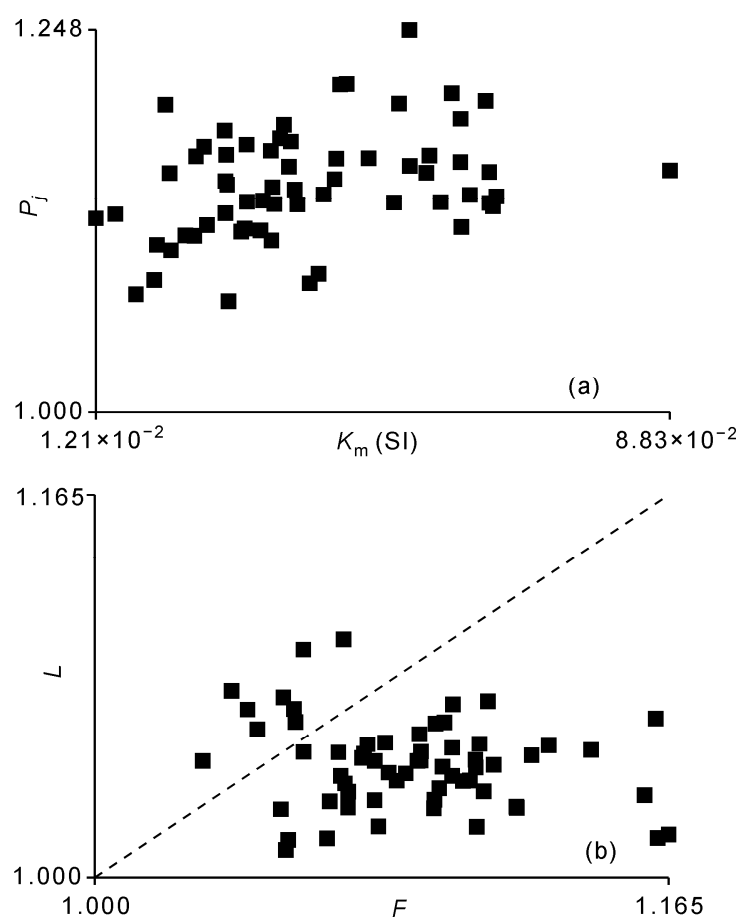

Figure 7 (a) Degree of magnetic anisotropy $\left(P_{j}\right)$ versus mean susceptibility $\left(K_{\mathrm{m}}\right)$ for the Wanning gabbro; (b) Flinn plot of the magnetic fabric of the Wanning gabbro. 
Flinn plot (Figure 7(b)). The AMS eigenvectors within each site are generally well grouped (Figure 8(a)). The maximum susceptibility axes $\left(K_{1}\right)$ dip northwards at relatively low angles $\left(<30^{\circ}\right)$. The mean orientation of $K_{1}$ is $1.9^{\circ} \angle 15.7^{\circ}$ respectively. The minimum susceptibility axes $\left(K_{3}\right)$ are mainly subvertical and dip to the south or SSW. The mean orientation of $K_{3}$ is $198.9^{\circ} \angle 73.6^{\circ}$.

$K_{1}$ axes of the Biandu gabbro samples (Figure 8(b)) are concentrated in the NNE with nearly horizontal dips. The mean orientation of $K_{1}$ is $22.9^{\circ} \angle 5.4^{\circ}$. The $K_{3}$ axes are subvertical and dip towards the WNW. The mean orientation of $K_{3}$ is $281.7^{\circ} \angle 63.9^{\circ}$.

The scalar AMS parameters of the Wanning diabase samples are as follows: mean $P_{j}=1.022, P_{j}$ of all samples is $\leqslant 1.2$ (Figure 9(a)). The majority of samples, except dyke wn4, lie within the oblate field of the Flinn plot (Figures 2,

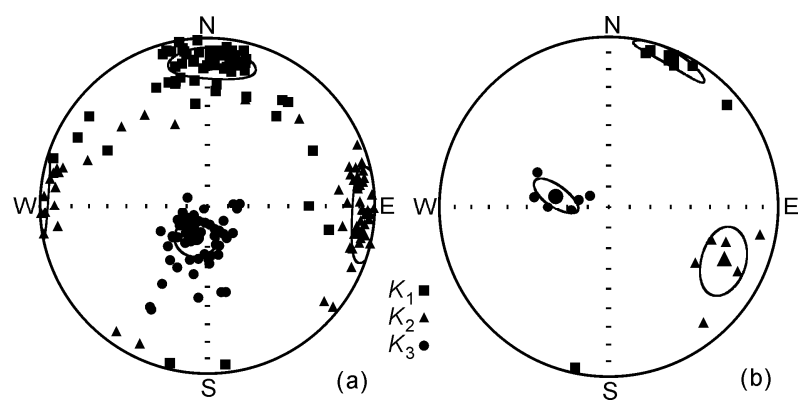

Figure 8 Equal-area projections of AMS in geographic coordinates. (a) Wanning gabbro; (b) Biandu gabbro.

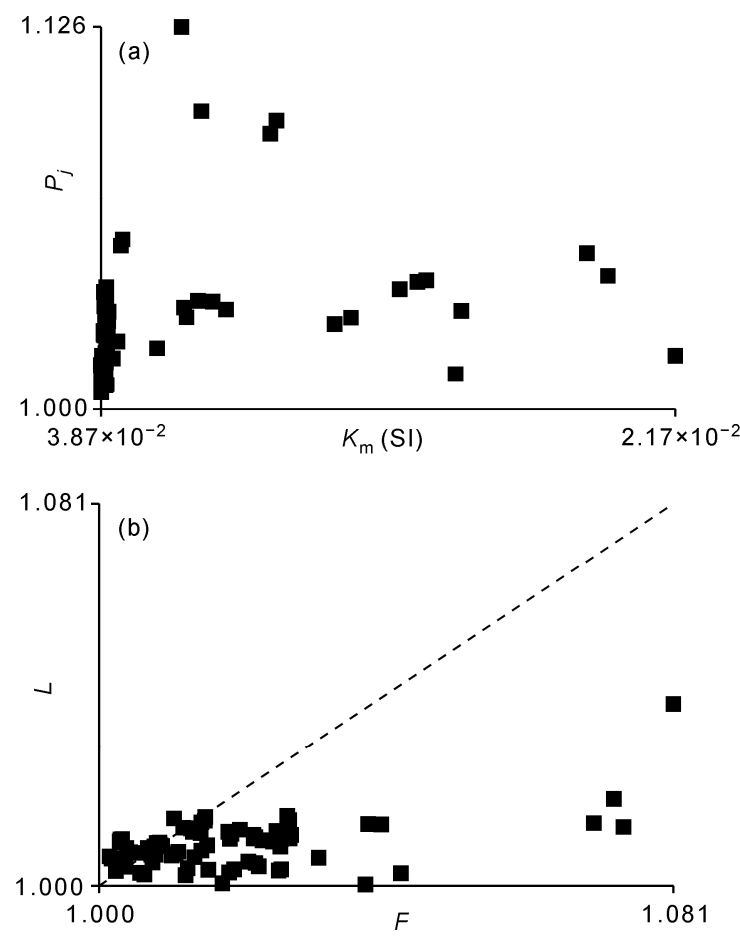

Figure 9 (a) Degree of magnetic anisotropy $\left(P_{j}\right)$ versus mean susceptibility $\left(K_{\mathrm{m}}\right)$ for the Wanning diabase; (b) Flinn plot of the magnetic fabric of the Wanning diabase. 9(b)). The spatial distribution of the three principal susceptibility axes is introduced in the Discussion section.

\section{Discussion}

\subsection{The reliability of AMS data}

It is a prerequisite of AMS studies regarding the emplacement mechanisms of intrusive rocks that we make certain of the relationship between magma flow and the magnetic fabric [30]. Statistical research of magnetic anisotropy $\left(P_{j}\right)$ of igneous rocks has been performed by Hrouda [31] who found that the value of $P_{j}$ was $<1.2$ for flow-related magnetic fabric whereas $P_{j}$ of deformational magnetic fabrics was $>1.2$ [31]. Values of $P_{j}$ for most samples in the Wanning area were $<1.2$, suggesting that this magnetic fabric is flow related.

The Wanning gabbro pluton has been intersected by an E-W trending granite dyke (Figure 2). If the granite dyke intrusion has engendered deformational magnetic fabric in the gabbro, then the $K_{3}$ axes should be perpendicular to the maximum stress direction. However, $K_{3}$ axes are subvertical, indicating that the magnetic fabrics preserved in the Wanning gabbro have not been significantly affected by the post-tectonic stresses [32]. In addition, the spatial distributions of the three principal susceptibility axes of the Wanning gabbro (Figure 8(a)) and diabase (Figure 2) are completely different, indicating a primary magnetic fabric has been preserved.

Late plastic deformation and solid-state deformation such as dynamic recrystallization and fragmentation were not observed in thin-sections of the Wanning gabbro and diabase samples. Moreover, thin sections parallel to the magnetic foliation plane were prepared to compare the mean direction of $K_{1}$ with the orientation of large phenocrysts or xenoliths which are likely to reflect the real flow direction. The preferred orientation of plagioclase phenocrysts taken from representative parts of the thin-sections are shown in rose diagrams (Figure 10). Deviations between the preferred orientation of plagioclase phenocrysts and $K_{1}$ axes in the gabbro (Figure 10(a)) and dyke (Figure 10(b)) samples were all $<10^{\circ}$. The deviation in one diabase sample (Figure 10(c)) was slightly larger but still $<30^{\circ}$. This shows that the magnetic fabric of the Wanning gabbro and diabase dykes is very consistent with the plagioclase rock fabric. This also suggests that the magnetic fabric is of primary origin.

In conclusion, magnetic anisotropy $\left(P_{j}\right)$, field observation, thin-section observation and rock fabric study all indicate that primary, flow-related magnetic fabrics are preserved in the Wanning gabbro and intruding diabase dykes.

\subsection{Emplacement mechanism}

After the concept of 3 types of magnetic fabric was advanced by Rochette et al. [7,8] and Tauxe et al. [9] it 

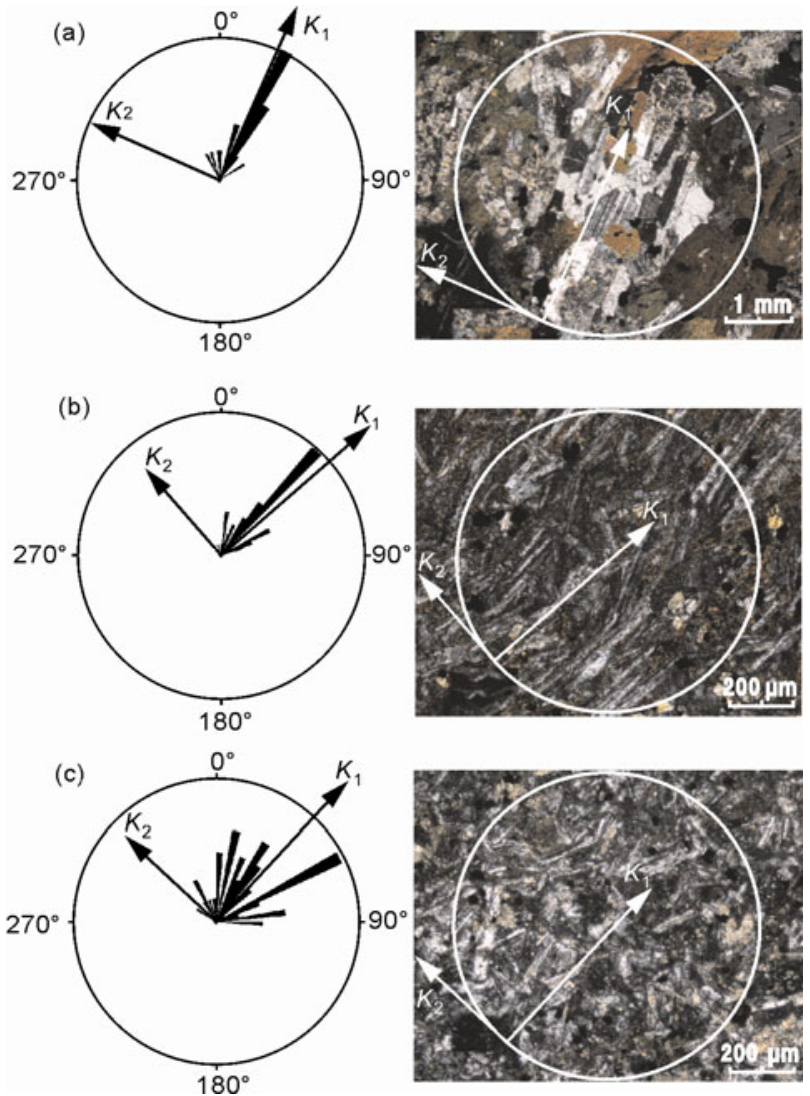

Figure 10 Oriented thin-sections in the magnetic foliation plane $\left(K_{1}-K_{2}\right)$ and rose diagrams of plagioclase phenocrysts contrasted with $K_{1}$. (a) Wanning gabbro; (b), (c) Wanning diabase.

became accepted that only normal fabric could be used to infer magma flow. Generally, $K_{1}$ axes of normal fabric are parallel to the dyke plane and are representative of the magma flow direction [7,8]. For all the Wanning diabase dykes, except dyke wn2, the angles between magnetic foliations and respective dyke walls are $<30^{\circ}$, with $K_{3}$ axes nearly perpendicular to the walls. This is indicative of normal fabric. The $K_{1}$ axes of the 7 diabase dykes are generally well grouped and dip toward the NNW or SSE at about $30^{\circ}$. It is suggested, therefore, that the Wanning diabase dykes intruded into pre-existing fractures in this orientation at a relatively low angle $\left(<30^{\circ}\right)$.

$K_{1}$ axes of the Wanning gabbro were inclined towards the north with a mean dip of $15.7^{\circ}$, suggesting lateral magma flow. The mean orientation of $K_{1}$ axes in the Biandu gabbro was $22.9^{\circ} \angle 5.4^{\circ}$, showing the lateral magma flow with NNE-SSW direction. As reported by Ernst [16,33], steeper flow planes may indicate the proximity of the magma source. Conversely, horizontal magma flow caused by lateral magma injection into fractures suggests a magma source that is located further away $[16,33]$. The dips of $K_{1}$ axes in the Wanning gabbro are steeper than in the Biandu gabbro, indicating that the Wanning gabbro was probably closer to the magma source than for the Biandu gabbro. This would imply that the magma source was located in the area far to the north of Wanning. In addition, the similar mineral composition and close emplacement times of the Wanning gabbro and diabase dykes indicate that they were most likely sourced from the same magma chamber [34]. The emplacement mode of the gabbro pluton appears to have involved emplacement from the north towards the south at a low ascent angle whereas the diabase dykes were emplaced from the NNW towards the SSE at low to moderate angles.

\subsection{Regional geological implications}

Geochronological and geochemical study of the Wanning gabbro pluton and diabase dykes by Tang et al. [19] suggests that they were emplaced in the early Triassic Period. This indicates that the collision and suturing between the micro-blocks in Hainan, or Hainan plate and South China plate, was complete by $240 \mathrm{Ma}$. At 240-230 Ma (post- collision) Hainan was in an intracontinental extensional tectonic setting due to stress relaxation during Indosinian orogeny. The Wanning gabbro and diabase dykes were emplaced in such a tectonic setting.

In the area south of the Changjiang-Qionghai fault and NW of Wanning, Indosinian granitic rocks are widely distributed, which are represented by the Wuzhishan granitic rock mass. In addition, the magnetic fabric shows that the magma source was located far to the north of Wanning. Hence, we can infer that basic rocks may exist beneath the Indosinian granite in the area to the north of Wanning. Further geological and geophysical exploration is needed to verify this.

\section{Conclusions}

Primary, flow-related magnetic fabrics are preserved in the Wanning gabbro pluton and associated diabase dykes. These fabrics can be used to infer the emplacement mechanism of these rocks. The Wanning gabbro pluton is characterized by emplacement from the north to the south at a low ascent angle, whereas the diabase dykes appear to have been emplaced from the NNW towards the SSE at low to moderate angles. The magma source was most likely located far to the north of Wanning. The overall evidence leads to the conclusion that the Wanning gabbro pluton and diabase dykes were the products of pulsative intrusion from the same magma source far to the north of Wanning. This further suggests that basic rocks (gabbro) may exist beneath the Indosinian granite in the area to the north of Wanning.

This work was supported by the National Basic Research Program of China (2007CB411706) and the National Natural Science Foundation of China (40274014).

1 Ellwood B B. Flow and emplacement direction determined for selected basaltic bodies using magnetic susceptibility anisotropy meas- 
urements. Earth Planet Sci Lett, 1978, 41: 254-264

2 Hargraves R B, Johnson D, Chan C Y. Distribution anisotropy: The cause of AMS in igneous rocks? Geophys Res Lett, 1991, 18: 2193-2196

3 Park J K, Tanczyk E, Debarats A. Magnetic fabric and its significance in the 1400 Ma Mealy diabase dykes of Labrador, Canada. J Geophys Res, 1988, 93: 13689-13704

4 Zhu R X, Shi C D. Anisotropy of magnetic susceptibility of Hannuoba basalt, northern China: Constraints on the vent position of the lava sequences. Geophys Res Lett, 2003, 30: 1066

5 Khan M A. The anisotropy of magnetic susceptibility of some igneous and metamorphic rocks. J Geophys Res, 1962, 67: 2867-2875

6 Knight M D, Walker G P L. Magma flow direction in dykes of Koolau Complex, Oahu, determined from magnetic fabric studies. J Geophys Res, 1988, B5: 4301-4319

7 Rochette P, Jackson M, Aubourg C. Rock magnetism and the interpretation of anisotropy of magnetic susceptibility. Rev Geophys, 1992, 30: 209-226

8 Rochette P, Aubourg C, Perrin M. Is this magnetic fabric normal? A review and case studies in volcanic formations. Tectonophys, 1999, 307: 219-234

9 Tauxe L, Gee J S, Staudigel H. Flow direction in dikes from anisotropy of magnetic susceptibility data: The bootstrap way. J Geophys Res, 1998, 103: 17775-17790

10 Cañón-Tapia E. Anisotropy of magnetic susceptibility of lava flows and dykes: A historical account. Geol Soc Spec Publ, 2004, 238: 205-225

11 Callot J P, Guichet X. Rock texture and magnetic lineation in dykes: A simple analytical model. Tectonophys, 2003, 366: 207-222

12 Hrouda F, Faryad S W, Jeřábek P, et al. Primary magnetic fabric in an ultramafic body (Moldanubian Zone, European Variscides) survives exhumation-related granulite-amphibolite facies metamorphism. Lithos, 2009, 111: 95-111

13 Cañòn-Tapia E, Herrero-Bervera E. Sampling strategies and the anisotropy of magnetic susceptibility of dykes. Tectonophys, 2009, 466: 3-17

14 Ji X L, Wang L, Pan Y X. Magnetic fabrics of the Fangshan pluton in Beijing and constraints on its emplacement (in Chinese). Chin J Geophys, 2010, 53: 1671-1680

15 Xie J Q, Zhang G W, Lu R K, et al. Magnetic fabric studies of Wenquan granite pluton in western Qinling Mountains and implications for emplacement mechanism (in Chinese). Chin J Geophys, 2010, 53 : 1187-1195

16 Ernst R E, Baragar W R. Evidence from magnetic fabric for the flow pattern of magma in the Mackenzie giant radiating dyke swarm. Nature, 1992, 356: 511-513

17 Raposo M I B, D'Agrella-Filho M S. Magnetic fabrics of dike swarms from SE Bahia State, Brazil: Their significance and implications for Mesoproterozoic basic magmatism in the São Francisco Craton. Precambrian Res, 2000, 99: 309-325

18 Curtis M L, Riley T R, Owens W H, et al. The form, distribution and anisotropy of magnetic susceptibility of Jurassic dykes in H.U. Sver-drupfjella, Dronning Maud Land, Antarctica: Implications for dyke swarm emplacement. J Struct Geol, 2008, 30: 1429-1447

19 Tang L M, Chen H L, Dong C W, et al. Triassic neutral and basic rocks in Hainan Island, geochemistry and their geological significance. Chin J Geol, 2010, 45: 1139-1155

20 Lowrie W. Identification of ferromagnetic minerals in a rock by coercivity and unblocking temperature properties. Geophys Res Lett, 1990, 17: 159-162

21 Day R, Fuller M, Schmidt V A. Hysteresis properties of titanomagnetites: Grain size and compositional dependence. Phys Earth Planet Inter, 1977, 13: 260-267

22 Dunlop D J. The rock magnetism of fine particles. Phys Earth Planet Inter, 1986, 26: 1-26

23 Li C X, Guo Z J, Meng Z F, et al. The rock magnetism of the Neogene sediments in north of Tianshan. Sci China Ser D-Earth Sci, 2006, 36: 988-997

24 Zhu R, Lin M, Pan Y. History of the temperature-dependence of susceptibility and its implications: Preliminary results along an E-W tran-sect of the Chinese Loess Plateau. Chin Sci Bull, 1999, 44 (Suppl 1): 81-86

25 Krása D, Herrero-Bervera E. Alteration induced changes of magnetic fabric as exemplified by dykes of the Koolau volcanic range. Earth Planet Sci Lett, 2005, 240: 445-453

26 Liu Q S, Liu Z D, Liu Q S, et al. Determination of primary magnetic minerals of a weathered metapelite xenolith from Zhouba region, North China, by combining thermomagnetic runs and low-temperature measurements (in Chinese). Chin J Geophys, 2005, 48: 876-881

27 Hu S Y, Wang S M, Appel E. Remanence acquisition and its alteration on sediments. Chin Sci Bull, 1998, 43: 1421-1434

28 Deng C L, Zhu R X, Verosub K L, et al. Mineral magnetic properties of loess/paleosol couplets of the central Loess Plateau of China over the last 1.2 Myr. J Geophys Res, 2004, 109: B01103

29 Jelinek V. Characterization of the magnetic fabric of the rocks. Tectonophys, 1981, 79: 63-67

30 Henry B. The magnetic fabric of the Egletons granite (France): Separation and structural implication. Phys Earth Planet Inter, 1988, 51: 253-263

31 Hrouda F. Magnetic anisotropy of rocks and its application in geology and geophysics. Surv Geophys, 1982, 5: 37-82

32 Raposo M I B, Gastal M C P. Emplacement mechanism of the main granite pluton of the Lavras do Sul intrusive complex, South Brazil, determined by magnetic anisotropies. Tectonophys, 2009, 466: 18-31

33 Ernst R E. Magma flow directions in two mafic Proterozoic dyke swarms of the Canadian shield, as estimated using anisotropy of magnetic susceptibility data. In: Parker A J, Rickwood P C, Tucker D H, eds. Mafic Dykes and Emplacement Mechanisms. Rotterdam: Balkema, 1990. 231-235

34 Almeida F F M, Carneiro C D R, Machado J D L, et al. Magmatismo Pós-Paleozóico no Nordeste Oriental do Brasil. Rev Brasil Geociê, 1988, 18: 451-462

Open Access This article is distributed under the terms of the Creative Commons Attribution License which permits any use, distribution, and reproduction in any medium, provided the original author(s) and source are credited. 